\title{
ALA candidates" forum encourages lively debate
}

\author{
By Charles Bunge, Marilyn Gell Mason, and Betty J. Turock
}

\section{What the candidates plan for ALA}

$\mathbf{T}$ he ALA Presidential Candidates' Forum at the 1994 Midwinter Meeting in Los Angeles departed from the usual canned question format to allow unrehearsed questions from the audience. The new format encouraged lively discussion at the forum and CERL News asked each candidate to select one or more of the issues that came up and discuss for our readers how they will address them if elected president of ALA.

\section{Charles Bunge}

I appreciate this opportunity to share my views with members of ACRL. As president of another division (RASD), I have learned that ALA can accomplish its mission only if it has strong divisions. I commend ACRL members, your elected and appointed leaders, and your staff on your effectiveness at addressing the needs of academic libraries and librarians.

Many important issues were raised in the Presidential Candidates' Forum at Midwinter, and it is important that ALA members know the thoughts of candidates on such issues. However, I believe that, much more important than a candidate's specific position on one or another issue, is his or her commitment to openmindedness and skill at encouraging and $\mathrm{fa}^{-}$ cilitating broad discussion of issues, building real consensus, and leading the effective development and implementation of programs that reflect that consensus. I am deeply committed to this leadership role, and I have spent some
25 years in association work at all levels learning how to carry it out.

The issue that I will comment on here is ALA's current self-study effort. This study provides an opportunity for ALA to address a growing perception among our members that ALA has lost its way and is ineffective at pursuing its priorities. It is crucial that we seize this opportunity to change ALA where it needs changing and to affirm those aspects of the association that are working well. As a member of the ALA Executive

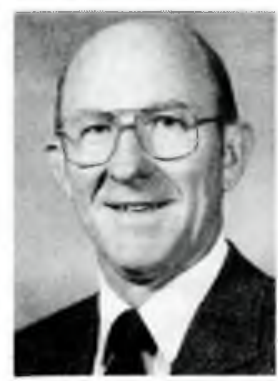

Charles Bunge
Board and as president, I would work hard to make the completion and implementation of the self-study part of a broad effort to create in our leadership and in our members a renewed sense of excitement about ALA- a positive, cando spirit that we are a focused, productive organization that is actively and aggressively able to be of real help to libraries and librarians in a wide range of contemporary and important areas.

The challenge, of course, is to make ALA that sort of organization. The report produced by Dadie Perlov as part of the self-study contains many important findings and recommendations. Along with a great many other ALA members, I find myself in general agreement with much of the report.

On the whole, though, I believe that it is too early in the self-study process to adopt positions on specific issues. As an elected ALA 
leader, I will not try to have all the answers, but will work hard to keep the right questions and issues before ALA's members and leaders. I will listen carefully to your views and concerns and will facilitate honest and open discussion that leads to quality answers and positions. In implementing those answers and positions, I will encourage and try to model trust, civility, and a sense of humor in relationships among the various elements of the association, including those between divisions and central functions of ALA and those between elected leaders and our fine staff. I am eager to contribute to ALA's effectiveness in this way, and would appreciate your vote.

\section{Marilyn Gell Mason}

The library profession is facing a time of unprecedented challenge and opportunity. On the one hand, advances in computer and communications technologies promise electronic access to a world of information. On the other, libraries struggle with the reality of maintaining basic access to shrinking collections with declining budgets. The gap between the promise of tomorrow and the reality of today is wide and deep.

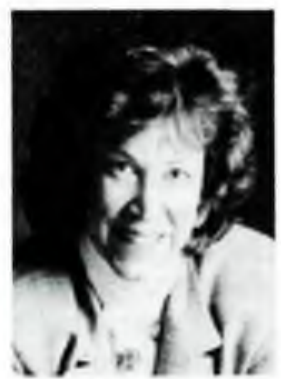

Marilyn Gell Mason
Bridging the gap will require more than technological expertise. It will also require adequate funding, organizational flexibility, and political savvy.

As members of the American Library Association we expect our association to play an important role in defining and resolving the major issues facing us. Instead, council and the executive board spend time and resources debating foreign policy and health care, and micromanaging the association. ALA must become more focused and responsive to the concerns of its members and a better advocate for libraries. This can best be accomplished by making sure that managers manage, that elected officials set policy, and that priorities are established and acted upon.

Change is needed, change that will make the association more effective in meeting the needs of its members. Two recommendations of the recently released Perlov report are especially important to achieving this goal: 1) place

\section{Full Duty by Howard Coffin is...}

"A sound and valuable addition to Civil War and regional history collections." -Booklist

“...a remarkable story." -Associated Press

“...that rare Civil War gem: a story that makes that remarkable and tragic war come alive and seem more human."

-Ken Burns, director of the PBS Civil War series
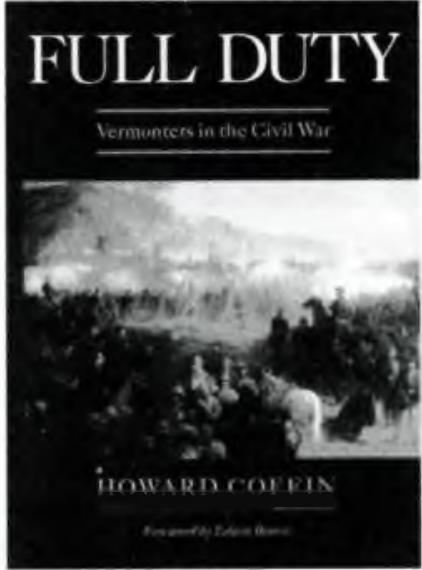

Full Duty

Vermonters in the Civil War Howard Coffin 376 pp $\bullet 0-88150-274-X$ E533.9.C64 • 973.7'443 $\$ 30.00$

Available from your wholesaler or from The Countryman Press PO Box 175

Woodstock, VT 05091 $800 / 245-4151$ 
responsibility for administration of the association clearly in the hands of the executive director, with council and the executive board responsible for setting direction and determining priorities; and 2) provide for the development of new leadership and expand participation in governance of the association by establishing term limits for council and the executive board.

By establishing clear lines of responsibility, a mechanism for broadening participation in decision-making, and a commitment to focusing the association's efforts on priority issues, we can strengthen the position of libraries in addressing the challenges and opportunities before us. We can assess the impact of technology, position libraries to play a pivotal role in the development of a national information infrastructure, and develop strategies for maintaining adequate budgets for ongoing services. Working together we can build the bridge between today's reality and tomorrow's promise.

\section{Betty J. Turock}

Even before the American economy slid into recession, many college and research libraries were mired in austerity. Now recovery is slow and unpredictable. Less money and more demand for service are part of everyday life. With the power of its 56,000 members and the magnitude of its financial resources, ALA has an obligation to lead academic libraries and librarians into an era of renewal.

For college and re-

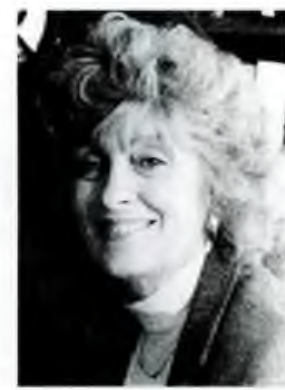

Betty J. Turock search libraries the Higher Education Act (HEA) is the major source of federal assistance. Yet, the administration's most recent request for funds zeroed out every title. Title II-C, too frequently perceived as funding only the richest libraries, was the single library program slated

\section{Get connected!}

Jobs and news now on the Internet

C\&RL NewsNet

gopher to "gopher.uic.edu", port 70 for elimination in Vice-President Gore's National Performance Review aimed at share of federal funds, when competition for limited resources is at an all-time high, will depend in large measure on the effort ALA makes to enlist ACRL'S expertise in articulating a vision that includes a vital role for academic libraries in our country's future.

While funding must be at the top of ALA's action agenda, policy decisions made in Washington with the greatest effect on the future of academic libraries center around the National Information Infrastructure (NII). Corporate interests have dominated debates over the shape of the emerging NII. ALA must cultivate champions in Congress, among the people, and within the ranks of librarians to ensure that college and research libraries are on the playing field, not watching from the sidelines, as this momentous telecommunications juncture takes form. Our association's strong voice is needed to convince policymakers that academic libraries are natural on-ramps which will offer equitable entry to the emerging information superhighway, but first they will need rebuilding and investment to bring their technology up to capacity. Only full participation by college and research libraries in forging the NII can ensure affordable access for their students and faculty.

We must organize ALA to take swift action, restructure our legislative agenda, forge coalitions, and initiate public awareness campaigns to relentlessly communicate the role college and research libraries will play in the economic, social, and technological environment of the 21st century.

As president, I will work with you to ensure that ALA helps college and research libraries fulfill their mission by: 1) developing legislation aimed at winning a bigger piece of the fiscal pie at the local, state, and national levels; 2) actively participating in the political process to convince policymakers that college and research libraries must be full partners in establishing the nation's information superhighway; and 3) initiating new public awareness programs, alliances, and coalitions to persuade the people and their political leaders that a resurgence of support for academic libraries is critical to the economic vitality, increased innovation, and productivity of our nation.

Together we must seize the initiative to make support for college and research libraries a national priority by promoting the dynamic role they will play in shaping the future. 


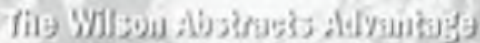

Wilson Abstracts give you the advantage of meeting all of your patrons' periodical research needs at a fraction of the price of fulltext resources. The six new databases-covering the areas of science, technology, art, education, the humanities, and social sciences-are modeled after Wilson's popular Reoders' Gvide Abstrocts and Wilsom Business Abstracts, and enhance access to information for all researchers.

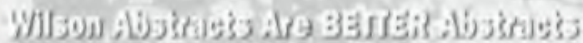

Written by professional abstractors, Wilson Abstracts set the standard. Each abstract ranges from 50 to 150 words in length and often contains all the needed information-including facts and figures-making it unnecessary to locate the original article. The detailed abstracts help preserve your periodical collection and speed research. Even when a given article is not available in your library, you can count on Wilson Abstracts to accurately convey the content, tone, and scope of the original text-every time!

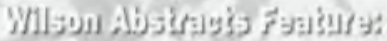

- Comprehensive indexing and abstracting

- Full, informative abstracts that speed research and often substitute for the original article

- Straightforward subject terms for one-stop searching

- Approximately ten years of indexing coverage in each database

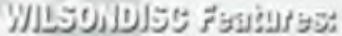

- Monthly disc updates for most databases

- Unlimited online access to the corresponding WILSONLINE database

- Generous networking policies for single and multiple institutions

- The privilege of keeping all discs

- Three WILSONDISC search modes that accommodate all users.

t)

Call 800-3576770 today for your 90-day Wilson Abstracts trial on WILSONDISC. Wilson Abstracts are also available online and on tape.

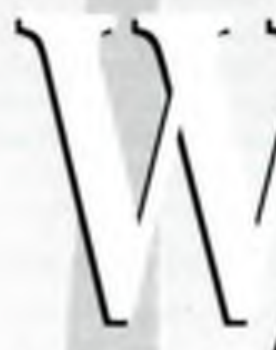

THE H.W.
WILSON
COMPANY
Sharing Knowledre Sharing Kanou
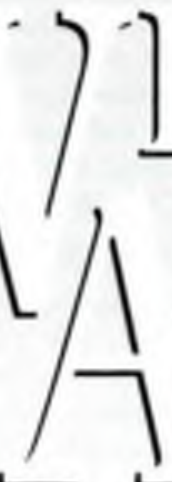

\section{(1)}

pplied serves 3 Ioshinolos Abstrasts

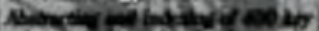

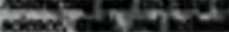
crials

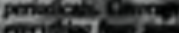

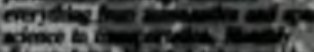
detwos

$$
\text { itex }
$$

Wilson Ant Absincts

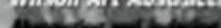

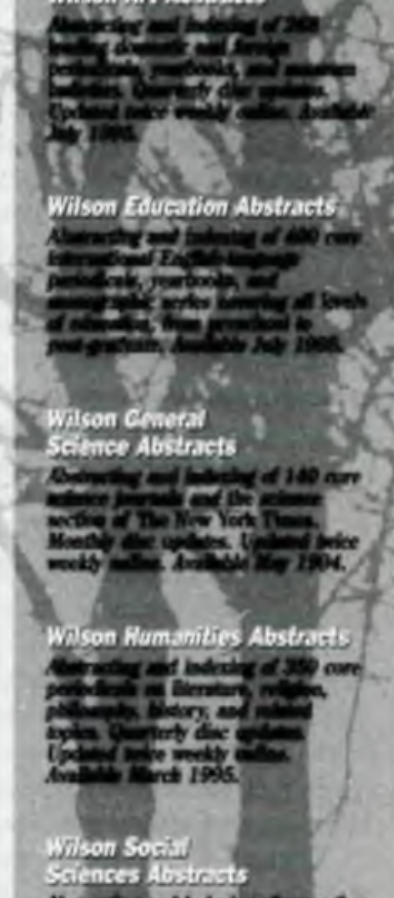

Wilson Elocetion Abstracts:

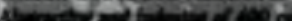

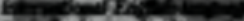

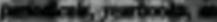

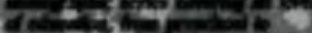
$=\sin ^{2}+2$ wilson comethi Scidnee Abstracts

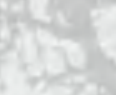

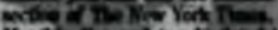

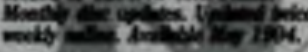
pran 